\title{
Dynamics of haemocytes from Pseudosuccinea columella circulating infected by Fasciola bepatica
}

\author{
Dinâmica de hemócitos circulantes de Pseudosuccinea columella infectados por Fasciola hepatica \\ Vinicius Marques Antunes Ribeiro'; Aytube Lucas Coaglio' ${ }^{1}$; Fernando Luiz Pereira Oliveira² \\ Cíntia Aparecida de Jesus Pereira ${ }^{1}$; Walter dos Santos Lima ${ }^{1 *}$
}

\begin{abstract}
${ }^{1}$ Departamento de Parasitologia, Instituto de Ciências Biológicas, Universidade Federal de Minas Gerais - UFMG, Belo Horizonte, MG, Brasil

${ }^{2}$ Universidade Federal de Ouro Preto - UFOP, Ouro Preto, MG, Brasil
\end{abstract}

Received June 5, 2017

Accepted August 30, 2017

\begin{abstract}
The lymnaeids are important in the epidemiology of Fasciola hepatica, a neglected and endemic zoonosis. The interaction between the internal defense system of Pseudosuccinea columella and $F$. hepatica has been little studied. In the present study the effect of infection by $F$. hepatica on P. columella circulating haemocytes was investigated. Changes in the average number of total circulating haemocytes have been observed at 30 minutes post-infection and 1, 7, 10, 14, 21, 28 and 50 days post-infection (dpi). Miracidia were observed head-foot and mantle at 30 minutes post-infection. Miracidia/Sporocysts in the mantle skirt $1 \mathrm{dpi}$, and fully formed sporocysts were observed in the head-foot at $7 \mathrm{dpi}$. Rediae became evident at $10 \mathrm{dpi}$ and were located between the haemocoel and the muscles from $14 \mathrm{dpi} ; 0 \mathrm{dpi}$, the rediae in the digestive gland contained cercariae. The statistical analysis of the total haemocytes of $P$. columella infected by $F$. hepatica showed significant differences on the 30 minutes post-infection and 1, 14,21, and $28 \mathrm{dpi}$ in comparison to uninfected molluscs $(0 \mathrm{dpi})$. Therefore, the interference observed on the internal defence system of $P$. columella may have direct association with the development of $F$. hepatica.
\end{abstract}

Keywords: Fasciola hepatica, haemocytes, Pseudosuccinea columella.

\section{Resumo}

Os limnaeideos são importantes na epidemiologia de Fasciola hepatica, uma zoonose negligenciada e endêmica. A interação entre o sistema interno de defesa de Pseudosuccinea columella e $F$. hepatica tem sido pouco estudada. No presente estudo, investigou-se o efeito da infecçáo por $F$. hepatica nos hemócitos circulantes de $P$. columella. Alteraçóes no número médio de hemócitos circulantes foram observadas aos 30 minutos e 1, 7, 10, 14, 21, 28 e 50 dias após a infecção (dpi). Miracídios foram observados na regiáo cefalopodal e manto aos 30 minutos após a infecçáo. Miracídio/esporocistos foram observados no colar do manto ao $1 \mathrm{dpi}$, e esporocistos totalmente formados na regiáo cefalopodal aos 7 dpi. Rédias tornam-se evidentes aos 10 dpi entre a hemocele e músculos a partir de 14 dpi; e rédias com cercárias próximas a glândula digestiva aos 50 dpi. A análise estatística dos hemócitos totais de $P$. columella infectados por $F$. hepatica demonstrou diferenças significativas nos 30 minutos pós-infecçáo e 1, 14, 21 e 28 dpi em comparação aos moluscos não infectados ( $0 \mathrm{dpi})$. Portanto, a interferência observada no sistema de defesa interna de P. columella pode ter associação direta com o desenvolvimento de F. hepatica.

Palavras-chave: Fasciola hepatica, hemócitos, Pseudosuccinea columella.

\section{Introduction}

Fasciola hepatica (Trematoda: Digenea) is a parasite of hepatic ducts of several mammal species, including ruminants, rabbits, swine, rodents and humans, which are the definitive hosts, and lymnaeid snails act as intermediate host. This trematode exhibits a wide distribution,

*Corresponding author: Walter dos Santos Lima. Departamento de Parasitologia, Instituto de Ciências Biológicas, Universidade Federal de Minas Gerais -- UFMG, Av. Presidente Antônio Carlos, 6627, CEP 31270-901, Belo Horizonte, MG, Brasil. e-mail: wlima@icb.ufmg.br is important as a zoonotic parasite, and causes great financial loss in cattle breeding due mainly to liver condemnation (LIMA et al., 2009; VAN DER VOORT et al., 2013). Pseudosuccinea columella is the most frequent intermediate host of $F$. hepatica in the South and Southeast Brazil (COELHO et al., 2008). This is probably due to its high genetic variability, sympatric and allopatric association that may vary according to the origin of the snails and flukes involved (CARDOSO et al., 2006; COELHO et al., 2009). 
Adult flukes settle into their definitive hosts hepatic ducts, and eggs are released into the external environment with the host faeces. In watercourses, miracidia develop within the eggs and hatch after 12-14 days under favourable light, temperature and humidity conditions. Propelled by their cilia, miracidia then swim in search of a lymnaeid, penetrate the host using cytolytic substance actions, and transform into sporocysts, which, in turn, yield the rediae. Several cercariae develop within the rediae and then exit the mollusc and encyst upon contact with a substrate, such as aquatic vegetation, to convert into metacercariae, the infectious form. The definitive host is infected through ingesting metacercariae.

Studies on the interaction between $F$. hepatica and lymnaeids are limited due to several factors involving both the parasite and intermediate host. Despite the high specificity between molluscs and trematodes, immunobiological studies between $F$. hepatica and lymnaeids are little explored. Nevertheless, the recognition of the trematode by the mollusc's internal defense system, made by haemocytes and soluble factors present in the haemolymph, from the penetration of miracidium to the transformation of sporocyst followed by the formation of rediae until the release of cercariae, may resemble the associations reported for other digenetic trematodes and gastropod molluscs (PEREIRA et al., 2008; CARON et al., 2014; COUSTAU et al., 2015). Fluctuations in the number of Lymnaea stagnalis haemocytes in the haemolymph during infection by Trichobilharzia ocellata have been observed (VAN DER KNAAP et al., 1987; AMEN et al., 1991). Other factors that also affect the success of the intramollusc trematode are age, strain or geographical origin of the lymnaeids (GUTIÉRREZ et al., 2011; COELHO et al., 2009; DREYFUSS et al., 2012). When infected, lymnaeids change biology which may reflect on the survival rate (MENDES et al., 2008; VIGNOLES et al., 2015).

Thus, new research on the interaction between the internal defense system of $P$. columella and F. hepatica is important because any insight can aid in understanding this association that has been poorly explored in the literature. Additionally, fascioliasis is a neglected, endemic and expanding disease in several regions of the world, and because molluscs are the first hosts for this parasite, studies in this field might aid in discovering control alternatives for this parasitosis. Therefore the present study evaluated the course of infection by $F$. hepatica through the quantification of the circulating haemocytes and the histological analysis of the P. columella of the municipality of Confins, Minas Gerais, Brazil lineage.

\section{Materials and Methods}

\section{Mollusc source}

Specimens of the parental $P$. columella generation were collected in an oxbow lake of the Mata river (19 40 '50.34"S; $43^{\circ} 58$ '23.42”W) in the municipality of Confins, Minas Gerais state, Brazil. In the laboratory, the specimens were fed lettuce leaves and maintained at a mean temperature of $24^{\circ} \mathrm{C}$ in plastic tanks with water and polystyrene fragments to generate the spawn that gave rise to the specimens used during the experiment after reaching a mean size of $4-8 \mathrm{~mm}$.

\section{Miracidia and Pseudosuccinea columella infection}

Fasciola hepatica eggs were obtained from faeces of infected sheep, the experiment was approved by the Ethics Committee the Federal University of Minas Gerais (CEUA/UFMG), under protocol number $18 / 2016$. The eggs were transferred to Petri dishes containing dechlorinated water and incubated at $27^{\circ} \mathrm{C}$ for 12 days to develop miracidia (MENDES et al., 2008). After hatching, two miracidia per host specimen were collected with a Pasteur pipette and transferred to a polystyrene plate (FALCON 3047) containing $2 \mathrm{ml}$ of water for individual infection of each of the $P$. columella specimens with a mean shell length of $4-8 \mathrm{~mm}$. The plates were covered and exposed to a $60 \mathrm{~W}$ light bulb at a distance of $50 \mathrm{~cm}$ for $24 \mathrm{~h}$. After that, each well was analysed under a stereoscopic microscope at $40 \mathrm{X}$ magnification to confirm the infection. The molluscs were maintained in plastic containers at a average room temperature of $24^{\circ} \mathrm{C}$ and fed lettuce until they were used for the below described protocols.

\section{Haemolymph collection and quantification of haemocytes of Pseudosuccinea columella infected by Fasciola hepatica}

The molluscs were anesthetized 30 minutes post-infection and $0,1,7,10,14,21,28,50 \mathrm{dpi}$, by immersion in a Sodic Pentobarbital solution (Hypnol-Cristalia) at $0.4 \mathrm{mg} / \mathrm{ml}$ diluted in CBSS - Chernin 's Balanced Salt Solution ( $47.7 \mathrm{mM}$ of $\mathrm{NaCl}$, $2.0 \mathrm{mM}$ of $\mathrm{KCl}, 0.49 \mathrm{mM}$ of $\mathrm{Na}_{2} \mathrm{HPO}_{4}$ anhydrous, $1.8 \mathrm{mM}$ of $\mathrm{MgSO}_{4} .7 \mathrm{H}_{2} \mathrm{O}, 3.6 \mathrm{mM}$ of $\mathrm{CaCl}_{2} .2 \mathrm{H}_{2} \mathrm{O}, 0.59 \mathrm{mM}$ of $\mathrm{NaHCO}_{3}$, $5.5 \mathrm{mM}$ of glucose and $3 \mathrm{mM}$ trehalose, $\mathrm{pH}$ 7.2) for 4 hours at room temperature, modified from Martins-Sousa et al. (2001), once the anesthetic was diluted in CBSS. The shells were then cleaned with absorbent paper soaked in 70\% alcohol. A heparinized capillary tube of microhematocrit (Glasscyto -, 80UI/ml sodium heparin, $75 \mathrm{~mm}$ long $\mathrm{x} 1.6 \mathrm{~mm}$ external diameter) was inserted in circular motions in the head-foot region of $P$. columella until the muscles were transposed and the mollusc's body cavities were reached. Then, the extravasated haemolymph $(5-20 \mu \mathrm{l} / \mathrm{mollusc})$ was collected by capillarity and transferred to a plastic film in an ice bath. Snail hemolymph was collected from individual snails, using 15 animals/group/dpi, was divided into 5 pools each consisting of 3 molluscs. Each pool was individually analysed.

After a 1:10 dilution in CBSS/citrate/EDTA solution supplemented by $100 \mathrm{U} / \mathrm{ml}$ penicillin, $100 \mu \mathrm{g} / \mathrm{ml}$ streptomycin (Sigma, St. Louis MO, USA), containing 4\% Trypan Blue vital dye (Sigma, St. Louis MO, USA), the viability of the haemocyte population was estimated in $10 \mu$ of total haemolymph diluted 1:10 in CBSS buffer containing 0.4\% Trypan Blue (Sigma, St. Louis MO, USA). Membrane-damaged haemocytes allow the fast penetration of Trypan Blue and these blue cells were immediately counted in a Neubauer's chamber (MARTINS-SOUZA et al., 2003; PEREIRA et al., 2008). Three independent experiments were performed. Totalling 405 molluscs at the end of the experiment. 


\section{Histological analysis of Pseudosuccinea columella infected by Fasciola hepatica}

For the histological evaluation, five $P$. columella specimens were used for each of the following intervals: 30 minutes post-infection, $0,1,7,10,14,21,28,50 \mathrm{dpi}$, totalling 45 molluscs. The molluscs were immersed in Bouin's fluid for 24 hours for fixation. The mollusc tissues were then separated from the shells, dehydrated in a series of alcohol baths, cleared using xylol, and embedded in paraffin. Serial histological $5-7 \mu \mathrm{m}$ thick sections were mounted onto slides, stained with haematoxylin-eosin, and examined under an Olympus BX41N microscope coupled to an Olympus DP12 digital camera.

\section{Survival curve of Pseudosuccinea columella infected by Fasciola hepatica}

In order to analyse the survival curve, 70 infected $P$. columella and 70 uninfected $P$. columella were kept in tanks under the conditions described above. The tanks were monitored daily for 50 days to quantify the dead molluscs.

\section{Statistical analysis}

Statistical analysis was performed in the Graphpad Prism 5.0 software. The average number of the circulating haemocytes counts was compared between $F$. hepatica uninfected and infected P. columella, through the one-way ANOVA test followed by Tukey's post-test. Kaplan-Meier Survival Curves and the Log-Rank test were used to analyse mollusc survival.

\section{Results}

\section{Haemolymph collection and quantification of haemocytes of Pseudosuccinea columella infected by Fasciola hepatica}

Most the experimental period, the average number of total haemocytes present in the haemolymph was lower in the infected molluscs compared to uninfected specimens.

Such variations in the number of total haemocytes showed statistically significant differences in the 30 minutes post-infection, 14, 21 and 28 dpi intervals (Figure 1, Table 1).

Oscillations of haemocytes number were observed between 30 minutes post-infection and $7 \mathrm{dpi}$, when miracidium transformation into sporocyst occurred. At 30 minutes post-infection $(\mathrm{p}<0.05)$, a sudden dilution in the number of circulating cells was observed, contrary to what happened at $1 \mathrm{dpi}(\mathrm{p}<0.05)$. Between 7 and $10 \mathrm{dpi}$, the levels are similar to those observed in uninfected molluscs, an interval when free rediae were observed in the molluscs tissues. Reduced levels of circulating haemocytes also occurred among $14(\mathrm{p}<0.001)$, $21(\mathrm{p}<0.05)$ and $28(\mathrm{p}<0.05) \mathrm{dpi}$ in the haemolymph, a period when rediae were observed migrating through the haemocoel and $P$. columella tissues. At $50 \mathrm{dpi}$, however, a quantity of haemocytes was similar to that observed in uninfected molluscs (Figure 1).

In most the period under study, the average number of dead cells was low. Only on 1 and 7dpi the total haemocytes increase, coincided with an increase in the number of dead cells (Figure 1b).

\section{Histological analysis of Pseudosuccinea columella infected by Fasciola hepatica}

At 30 minutes post-infection, $F$. hepatica miracidia covered with remnant ciliated plates were observed in the connective tissue of the $P$. columella head-foot and mantle regions. Lacunae were observed around the miracidia in these regions, and ruptured muscle fibres were observed in the transverse and longitudinal planes (Figure 2a).

At $1 \mathrm{dpi}$, sac-shaped sporocyst containing round translucent cells were observed in the $P$. columella mantle skirt. The first evidence of ruptured connective tissue and lacunae formation around developing sporocysts. (Figure $2 \mathrm{~b}$ ).

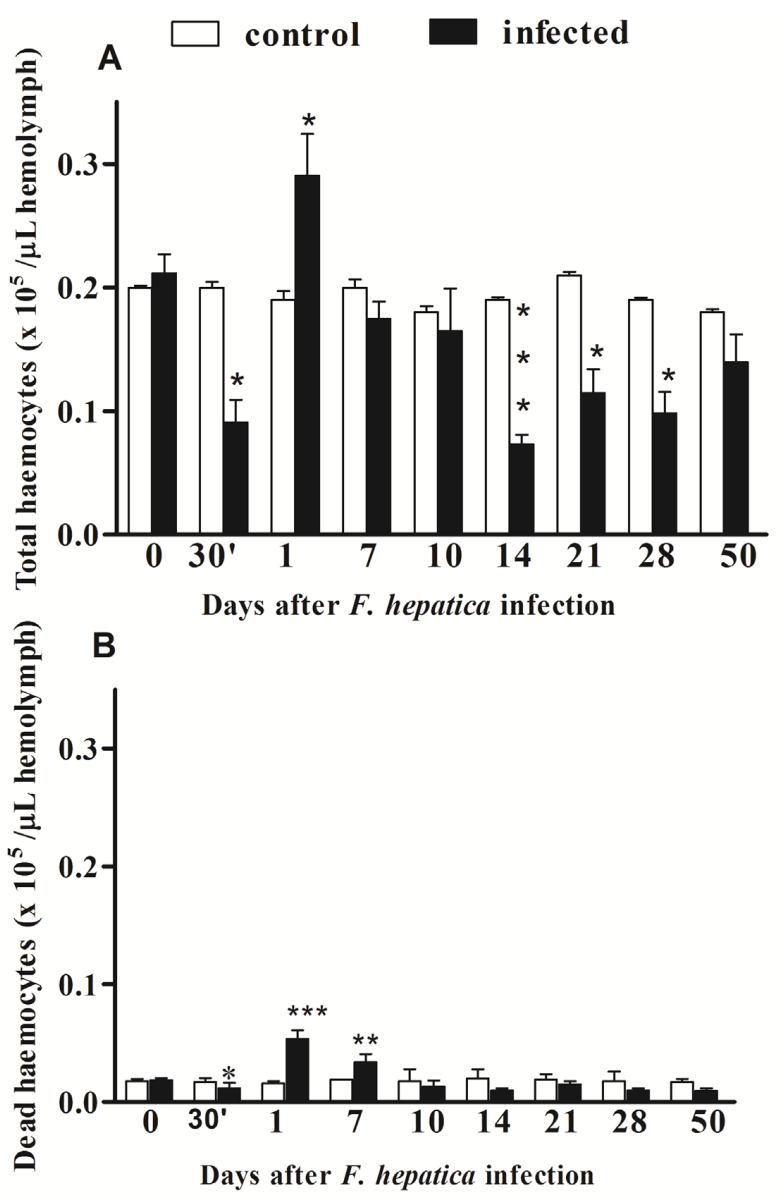

Figure 1. Total and dead circulating haemocytes during the development of Fasciola hepatica in Pseudosuccinea columella. Asterisks represent ${ }^{*}(p<0.05){ }^{* *}(p<0.01),{ }^{* * *}(p<0.001)$ the statistical difference between the number of haemocytes present in infected molluscs compared to uninfected ones. 
Table 1. Number of total and dead cells in hemolymph of Pseudosuccinea columella infected with Fasciola hepatica. Each point represent the average $\pm \mathrm{SD}$ and the experiment was repeated three times with similar results.

\begin{tabular}{cccccc}
\hline \multirow{2}{*}{ Interval of Infection } & \multicolumn{2}{c}{ Total cells $(\mathbf{x 1 0} / \mu \mathbf{L})$} & & \multicolumn{2}{c}{ Dead cells $(\mathbf{x 1 0} / \mu \mathbf{L})$} \\
\cline { 2 - 3 } \cline { 5 - 6 } & Infected & Control & & Infected & Control \\
\hline $30^{\prime}$ pos infection & $0.090 \pm 0.055^{\mathrm{a}}$ & $0.090 \pm 0.055$ & & $0.011 \pm 0.011^{\mathrm{a}}$ & $0.010 \pm 0.017$ \\
$1^{\circ}$ & $0.290 \pm 0.183^{\mathrm{a}}$ & $0.290 \pm 0.183$ & & $0.053 \pm 0.038^{\mathrm{c}}$ & $0.016 \pm 0.01$ \\
$7^{\circ}$ & $0.174 \pm 0.064$ & $0.174 \pm 0.064$ & & $0.033 \pm 0.031^{\mathrm{b}}$ & $0.019 \pm 0.00$ \\
$10^{\circ}$ & $0.165 \pm 0.103$ & $0.165 \pm 0.103$ & & $0.013 \pm 0.014$ & $0.018 \pm 0.03$ \\
$14^{\circ}$ & $0.073 \pm 0.044^{\mathrm{c}}$ & $0.073 \pm 0.044$ & & $0.009 \pm 0.011$ & $0.020 \pm 0.04$ \\
$21^{\circ}$ & $0.114 \pm 0.087^{\mathrm{a}}$ & $0.114 \pm 0.087$ & & $0.015 \pm 0.011$ & $0.019 \pm 0.020$ \\
$28^{\circ}$ & $0.098 \pm 0.066^{\mathrm{a}}$ & $0.098 \pm 0.066$ & & $0.010 \pm 0.006$ & $0.018 \pm 0.03$ \\
$50^{\circ}$ & $0.139 \pm 0.087$ & $0.139 \pm 0.087$ & & $0.009 \pm 0.009$ & $0.017 \pm 0.010$ \\
\hline
\end{tabular}

The letter "(a)" represents $\mathrm{p}<0.05$, the letter "b" represents $\mathrm{p}<0.01$, the letter "c" represents $\mathrm{p}<0.001$, which are statistical differences between the number of hemocytes of the infected group in relation to the group not infected.

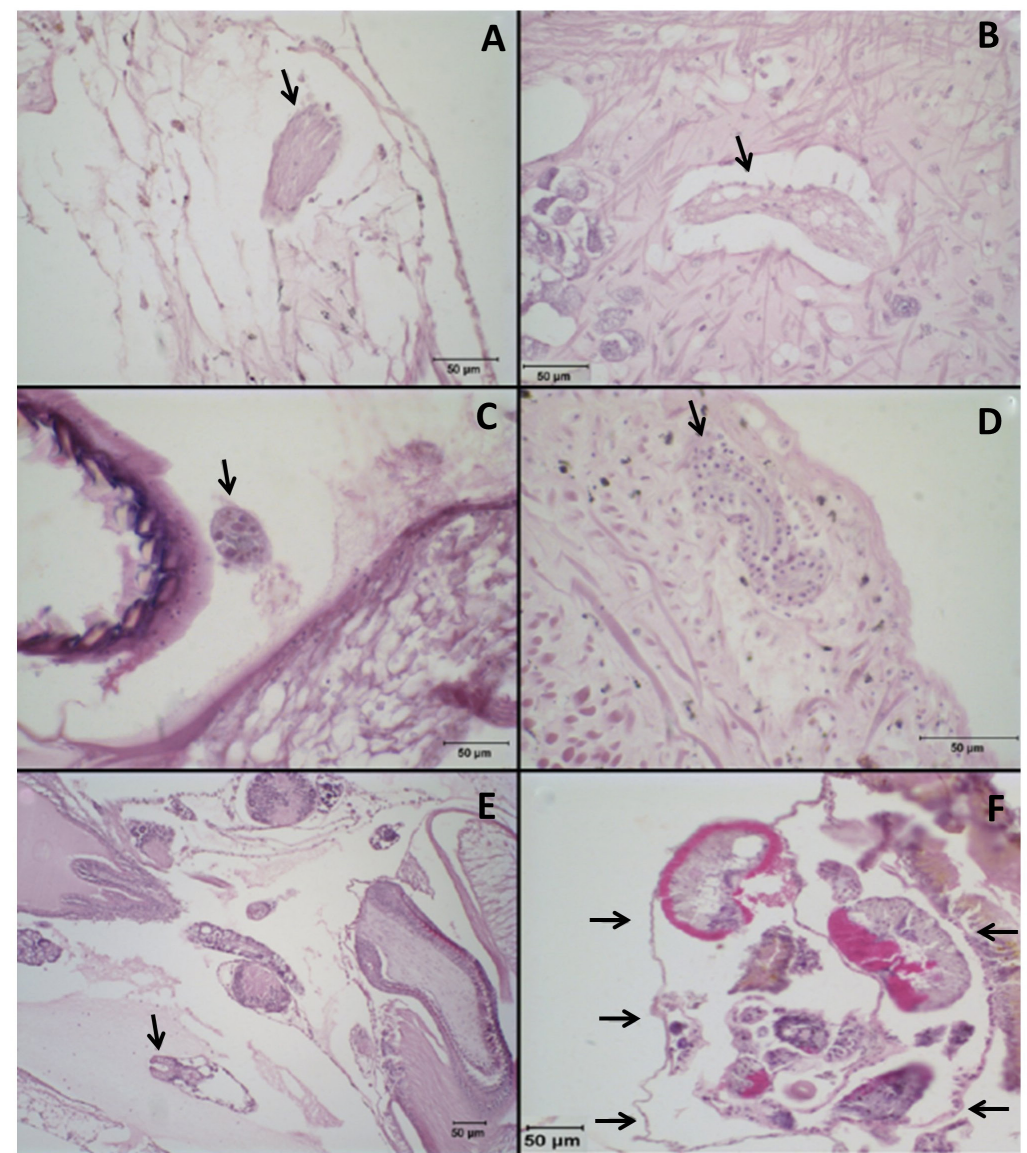

Figure 2. Histology of Pseudosuccinea columella infected by Fasciola hepatica. (A) Arrow: Miracidium at 30 minutes post-infection forming a gap at the mantle; (B) Arrow: Miracidium/Sporocysts head-foot region $1 \mathrm{dpi}$; (C) Arrow: Sporocysts near the radula at 7 dpi; (D) Arrow: Rediae at $10 \mathrm{dpi}$ in the head-foot region; (E) Arrow: Rediae at $14 \mathrm{dpi}$ in the haemocele and it is shown inset; (F) Arrows: Redia at 50 dpi in the digestive gland harbouring cercariae.

At $7 \mathrm{dpi}$, round sporocysts were present in the P. columella head-foot region near the host. The outer muscle layer of these larvae was developed and surrounded germinal cells with intense basophilia, which would eventually develop into rediae radula (Figure 2c).

At 10 dpi, developing $F$. hepatica rediae were observed in the P. columella head-foot region and exhibited a pharynx as well as a caecum. This larval stage was present in lacunae of ruptured mollusc connective tissue, as well as cellular reactions were discrete (Figure 2d).

At $14 \mathrm{dpi}$, rediae in different developmental stages were free in the haemocoel (Figure 2e). Certain such rediae exhibited cells that would give rise to the tegument, pharynx, caecum and germinal cells, and other rediae exhibited the above structures. In the mollusc haemocoel, containing hemocytes was observed in the haemolymph around the rediae (Figure 2e). Rediae migration 


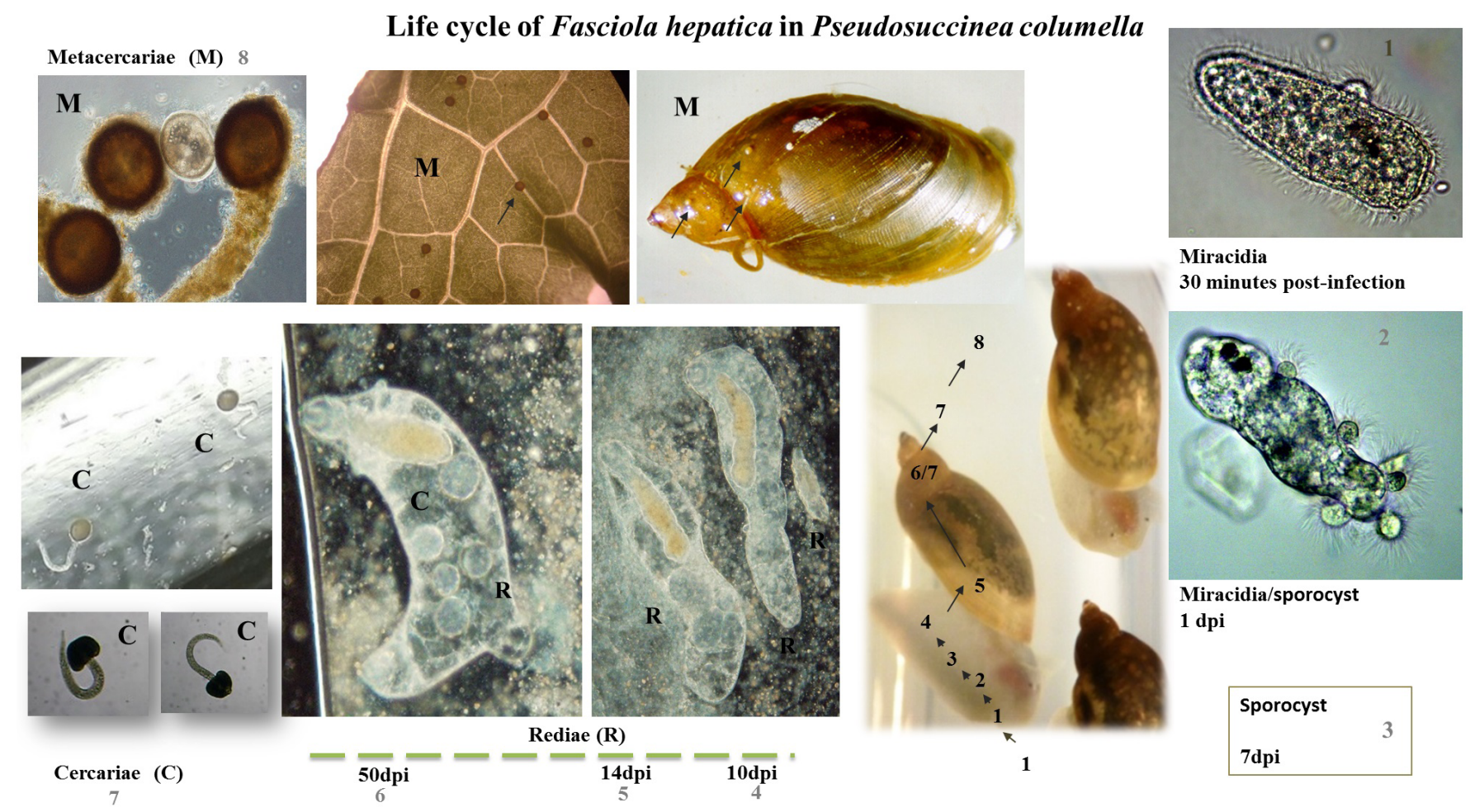

Figure 3. Schematic representation of the life cycle the Fasciola hepatica in Pseudosuccinea columella (1) Miracidium: 30 minutes post-infection $\rightarrow$ (2) Miracidium/sporocyst: $1 \mathrm{dpi} \rightarrow$ (3) Sporocyst: $7 \mathrm{dpi} \rightarrow(4,5,6)$ Rediae: 10,14,50dpi $\rightarrow$ (7) cercariae: 50 dpi $\rightarrow(8)$ metacercariae: 50 dpi.

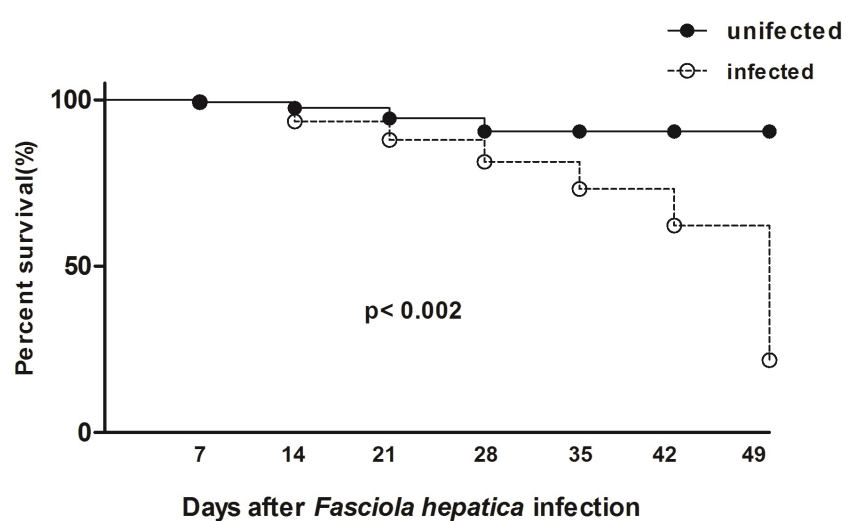

Figure 4. Survival curve of Pseudosuccinea columella infected by Fasciola hepatica. Statistically significant differences comparing between survival curve of the infected group was statistically different than the survival curve of uninfected group $p<0.002$.

happened until $28 \mathrm{dpi}$ with a similar pattern to $14 \mathrm{dpi}$ (data not shown).

At $50 \mathrm{dpi}$, the digestive glands exhibited rediae harbouring daughter rediae and developing cercariae as well as disorganised epithelial and connective tissue structures in the digestive gland lobules due to the parasite (Figure 2f). Both developing and fully developed cercariae were also observed within the rediae at $50 \mathrm{dpi}$. On this interval, presence of metacercariae adhered to the experimental tank was also observe, see also the scheme the life cycle of Fasciola hepatica in Pseudosuccinea columella (Figure 3)

\section{Survival curve of Pseudosuccinea columella infected by Fasciola hepatica}

Differences between the infected and uninfected molluscs survival curves were observed during the experiment $(p<0.002)$. In the infected group, the pattern of mortality increased from the $14 \mathrm{dpi}$. At the end of the $28 \mathrm{dpi}, 20 \%$ of the infected molluscs died, and between the 35 and 42 dpi plus $20 \%$ infected molluscs died. At the end of the experiment, only $20 \%$ of the infected molluscs were alive (Figure 4), while uninfected $92.5 \%$ survived.

\section{Discussion}

This study showed that the population of $P$. columella from Confins-MG is susceptible to F. hepatica, as reported for other populations of Brazilian P. columella from the Ribeira and Paraíba valleys, in the state of São Paulo (UETA 1980a, b; AMATO et al., 1986; OLIVEIRA et al., 2002), and from the meso-region of southern Minas Gerais and Pelotas, in the south of the country (COELHO et al., 2009). Recently, Dracz \& Lima (2014) observed the spontaneous elimination of $F$. hepatica cercariae by this gastropod, from the municipalities São José da Lapa, and Pedro Leopoldo-MG.

Studies evaluating changes in the internal defence system of $P$. columella during the development of $F$. hepatica in Brazilian molluscs are however scarce. The asexual multiplication process of the mollusc could induce changes in the average number of 
total circulating haemocytes of the infected molluscs, compared to uninfected ones.

At 30 minutes post-infection, there was a decrease of approximately twice the average total number of circulating haemocytes of $P$. columella in relation to uninfected molluscs, and yet no striking cellular infiltrate was observed close to the newly-penetrated miracidia in the molluscs. Van der Knaap et al. (1987) suggested that the decrease of the number of circulating haemocytes em L. stagnalis would have a direct association with the mobilization of these cells to the sites where miracidia penetrate induced of T. ocellata. Adema et al. (1994) observed that 30 minutes after in vitro interaction, haemocytes of different molluscs present different Echinostoma paraensei larval forms recognition patterns. This recognition pattern may be associated with the specificity of the mollusc-helminth interactions (PEREIRA et al., 2008). It should also be noted that the mollusc innate immune system, comprised of haemocytes and hemolymph soluble factors can recognize not only the parasite and excreted-secreted products (ES), but also the induced inflammation process (COUSTAU et al., 2015) a fact not demonstrated in this study.

At $1 \mathrm{dpi}$, the population of circulating haemocytes of $P$. columella increased to levels similar to those observed for the uninfected molluscs $(p<0.05)$. At $1 \mathrm{dpi}$, there was a loss of the ciliated plates of the miracidia of $F$. hepatica and the transformation into sporocysts occurred (DIAWARA et al., 2003). The authors Van der Knaap et al. (1987) demonstrated in L. stagnalis infected with T. ocellata, the increase phagocytic index of after haemocytes 24 hours of infection by the trematode. They attributed the possibility of haemocyte activation to the loosening of the miracidia ciliated plates, which would be phagocytized along with cellular debris from damaged tissues of the mollusc, during penetration of miracidia and development of parental sporocysts. This hypothesis can be corroborated by Gourbal et al. (2008) who reported, through proteomic studies of in vitro transformed sporocysts of $F$. hepatica that, after 24 hours, the ES may interfere with the recognition of haemocytes present in the mollusc haemolymph parasitized with the trematode. At $7 \mathrm{dpi}, F$. hepatica developed sporocysts in $P$. columella were observed, when the total average number of circulating haemocyte was restablished in the haemolymph, reaching values similar to those of uninfected molluscs. By histology, sporocysts near the radula were found. According to Humphries \& Yoshino (2003), the elimination of metazoan parasites, such as trematodes, by molluscs would be directly associated with the formation of multicellular capsules of haemocytes, in a coordinated action with soluble factors of the haemolymph. In the Biomphalaria spp. resistant to the trematode, after migration of haemocytes to the vicinity of the sporocyst, tegument was noted and there was also the release of products that destroyed and killed the parasite by cytotoxicity (PEREIRA et al., 2008), a fact not demonstrated in this study.

Beginning at $10 \mathrm{dpi}$, rediae were observed developing within lacunae of ruptured connective tissue in the $P$. columella head-foot region. Rediae were also observed in the haemocoel at $14 \mathrm{dpi}$. In the present study, $P$. columella tissue lesions caused by rediae were similar to the lesions observed by Diawara et al. (2003) in Galba truncatula that were naturally infected by F. hepatica. Despite the fact that during this infection interval, the parasite is more developed, the total circulating haemocyte profile is similar to that between $7 \mathrm{dpi}$ and uninfected molluscs. From $14 \mathrm{dpi}$ on, the average number of circulating haemocytes reduced three times in the circulating haemolymph, period when rediae migrated through the hemocoel towards the digestive gland of the mollusc. According to Yoshino et al. (2001), during the intra-mollusc development of trematodes, the interaction interface between the parasite and the intermediate host would be a dynamic medium, made up of cell membranes and non-cellular components of the mollusc, as well as the parasite tegument. These authors reported that in susceptible molluscs, the haemocytes were not linked to the sporocysts tegument due to the release of ES, camouflaging the parasite's internal defence system of the invertebrate host, in a similar way to what was observed in serial histological sections of this study at 14 dpi. Loker \& Hertel (1987) reported the approximation of hemocytes at $15 \mathrm{dpi}$ when $E$. paraense $i$ rediae was present in $B$. glabrata aorta and the number of haemocytes in the circulation was greater than that of the uninfected mollusc group. This contrasted with the results of this study, where there was a reduction of circulating haemocytes of $P$. columella during the release of the $F$. hepatica rediae, which may be related to the susceptibility of the species of lymnaeid to the development of the parasite.

In this study, however, from $10 \mathrm{dpi}$ on, F. hepatica rediae in the histological sections were observed, and the total number of circulating haemocytes in the haemolymph decreased and increased again at 50 dpi. According to Rondelaud et al. (2009), there may be 3 or 4 generations of $F$. hepatica rediae occurring from the $7 \mathrm{dpi}$ on the same Galba truncatula specimen, and the first generation of rediae produced daughter rediae, which in turn originated cercariae and thus the development of the rediae would occur normally, with no death of mother rediae in the first or second week of the infection. These authors observed that the daughter rediae could be released by the mother rediae in the same period in which the latter would be emerging from the sporocysts. This may explain the morphological differences between the rediae in the histological sections and the ones in the $P$. columella circulating haemocyte counts throughout the course of infection by F. hepatica in this study observed from 10 to $50 \mathrm{dpi}$.

Contrary to what was observed in this study, Van der Knaap et al. (1987) reported in L. stagnalis-T. ocellata the increase in the number of circulating haemocytes in every studied interval, from 7 to $91 \mathrm{dpi}$, period when the intramollusc transformation of miracidia into sporocysts and the release of cercariae. According to them, the proliferation of haemocytes was due to the recruitment of connective tissue haemocytes to the haemolymph of the molluscs, due to the fact that this was not observed in vitro. According to these authors, the haemocyte kinetics of trematode infected molluscs may be modulated during infection, depending on the combinations between host and parasite, as well as the experimental conditions. On the other hand, Amen et al. (1991) followed the development of $T$. ocellata in $L$. stagnalis through haemocyte count at 0,14, 28, 42 and $56 \mathrm{dpi}$ and histological analysis of the infected molluscs in the 2, 4, 6 and 7 wpi. These authors reported an increase in the number of haemocytes during the development of the parasite, of sporocysts at 14 dpi migrating from the head-foot to the digestive gland at $28 \mathrm{dpi}$, when this cell 
population decreased. An increase in the number of haemocytes also occurred between 42 and 56 dpi, intervals where sporocysts and early release of cercariae occurred. At $56 \mathrm{dpi}$, the number of circulating haemocytes was larger.

The percentage of dead haemocytes ranged (16-18\%) and although in this work was not tested the ES participation on the interaction between $F$. hepatica and $P$. columella, further studies are needed to understand the number the of dead cells found.

As for the average number of $P$. columella dead cells, it was statistically significant $(p<0.01)$ between the 30 minutes post-infection intervals and the uninfected molluscs. In the intervals between 1 and $7 \mathrm{dpi}$, the percentage of dead cells ranged from 16 and $18 \%$ and were similar to the viability levels accepted in the literature, as reported by Adema et al. (1994) in L. stagnalis haemocyte viability tests performed with trypan blue. A percentage of dead cells ranging between 19 and $11 \%$ was considered satisfactory, when the cells of these gastropods were recovered.

During an experimental infection of Lymnaea spp. by F. hepatica, parasite-host competition for energy reserves in the digestive glands began at $20 \mathrm{dpi}$ and intensified until $60 \mathrm{dpi}$, which promoted cell death in this gland (HUMICZEWSKA, 2000), reflecting on the mortality rate observed in infected molluscs, which happened in this study.

\section{Conclusion}

In this study, the interference observed on the internal defence system of $P$. columella may have a direct association with the development of $F$. hepatica, but future studies are needed to characterize the interaction of this host-parasite relationship.

\section{Acknowledgements}

We thank the funded by the Minas Gerais Research Foundation (Fundação de Amparo à Pesquisa do Estado de Minas Gerais FAPEMIG), (WSL, grant number 18898), the National Council for Scientific and Technological Development (Conselho Nacional de Desenvolvimento Científico e Tecnológico - CNPq) to (WSL, grant number 480469/2012-1).

\section{References}

Adema CM, Arguello DF 2nd, Stricker SA, Loker ES. A time-lapse study of interactions between Echinostoma paraensei intramolluscan larval stages and adherent hemocytes from Biomphalaria glabrata and Helix aspersa. J Parasitol 1994; 80(5): 719-727. PMid:7931907. http:// dx.doi.org/10.2307/3283251.

Amato SB, Rezende HE, Gomes DC, Freire NMS. Epidemiology of Fasciola hepatica infection in the Paraíba river valley, São Paulo, Brasil. Vet Parasitol 1986; 22(2-3): 275-284. PMid:3564331. http://dx.doi. org/10.1016/0304-4017(86)90115-9.

Amen RI, Tijnagel JM, van der Knaap WP, Meuleman EA, Lange-de Klerk ES, Sminia T. Effects of Trichobilharzia ocellata on hemocytes of Lymnaea stagnalis. Dev Comp Immunol 1991; 15(3): 105-115. PMid:2060680. http://dx.doi.org/10.1016/0145-305X(91)90001-F.
Cardoso PC, Caldeira RL, Lovato MB, Coelho PM, Berne ME, Müller $\mathrm{G}$, et al. Genetic variability of Brazilian populations of Lymnaea columella (Gastropoda: Lymnaeidae), an intermediate host of Fasciola hepatica (Trematoda: Digenea). Acta Trop 2006; 97(3): 339-345. PMid:16469288. http://dx.doi.org/10.1016/j.actatropica.2006.01.003.

Caron Y, Martens K, Lempereur L, Saegerman C, Losson B. New insight in lymnaeid snails (Mollusca, Gastropoda) as intermediate hosts of Fasciola hepatica (Trematoda, Digenea) in Belgium and Luxembourg. Parasit Vectors 2014; 7(1): 66. PMid:24524623. http://dx.doi.org/10.1186/17563305-7-66.

Coelho LH, Guimarães MP, Lima WS. Influence of shell size of Lymnaea columella on infectivity and development of Fasciola hepatica. J Helminthol 2008; 82(1): 77-80. PMid:18275634. http://dx.doi.org/10.1017/ S0022149X08873579.

Coelho LH, Lima WS, Guimarães MP. Sympatric and allopatric combinations of Lymnaea columella and Fasciola hepatica from southern and southeastern Brazil. J Helminthol 2009; 83(3): 285-288. PMid:19243641. http://dx.doi.org/10.1017/S0022149X09222930.

Coustau C, Gourbal B, Duval D, Yoshino TP, Adema CM, Mitta G. Advances in gastropod immunity from the study of the interaction between the snail Biomphalaria glabrata and its parasites: A review of research progress over the last decade. Fish Shellfish Immunol 2015; 46(1): 5-16. PMid:25662712. http://dx.doi.org/10.1016/j.fsi.2015.01.036.

Diawara M, Ayadi A, Rondelaud D. Fasciola hepatica: the development of tissue lesions and their frequencies in naturally-infected Galba truncatula. Parasitol Res 2003; 90(3): 257-260. PMid:12684887. http://dx.doi. org/10.1007/s00436-003-0856-z.

Dracz RM, Lima WS. Autochthonous infection of buffaloes and cattle by Fasciola hepatica in Minas Gerais, Brazil. Rev Bras Parasitol Vet 2014; 23(3): 413-416. PMid:25271466. http://dx.doi.org/10.1590/S198429612014054.

Dreyfuss G, Vignoles P, Rondelaud D. Local adaptation of the trematode Fasciola hepatica to the snail Galba truncatula. Parasite 2012; 19(3): 271275. PMid:22910670. http://dx.doi.org/10.1051/parasite/2012193271.

Gourbal BE, Guillou F, Mitta G, Sibille P, Thèron A, Pointier JP, et al. Excretory-secretory products of larval Fasciola hepatica investigated using a two-dimensional proteomic approach. Mol Biochem Parasitol 2008; 161(1): 63-66. PMid:18556074. http://dx.doi.org/10.1016/j. molbiopara.2008.05.002.

Gutiérrez A, Vázquez AA, Hevia Y, Sánchez J, Correa AC, HurtrezBoussès $S$, et al. First report of larval stages of Fasciola hepatica in a wild population of Pseudosuccinea columella from Cuba and the Caribbean. J Helminthol 2011; 85(1): 109-111. PMid:20637143. http://dx.doi. org/10.1017/S0022149X10000350.

Humiczewska M. Effect of Fasciola hepatica larvae on the ultrastructure of digestivegland of Galba truncatula. Wiad Parazytol 2000; 47(4): 647649. PMid:16886404.

Humphries JE, Yoshino TP. Cellular receptors and signal transduction in molluscan hemocytes: connections with the innate immune system of vertebrates. Integr Comp Biol 2003; 43(2): 305-312. PMid:21680438. http://dx.doi.org/10.1093/icb/43.2.305.

Lima WS, Soares LRM, Barçante TA, Guimarães MP, Barçante JMP. Occurrence of Fasciola hepatica (Linnaeus, 1758) infection in Brazilian cattle of Minas Gerais, Brazil. Rev Bras Parasitol Vet 2009; 18(2): 27-30. PMid:19602313. http://dx.doi.org/10.4322/rbpv.01802006.

Loker ES, Hertel LA. Alterations in Biomphalaria glabrata plasma induced by infection with the digenetic trematode Echinostoma paraensei. J Parasitol 1987; 73(3): 503-513. PMid:3598800. http://dx.doi.org/10.2307/3282128. 
Martins-Sousa RL, Negrão-Corrêa D, Bezerra FSM, Coelho PMZ. Anesthesia of Biomphalaria spp. (Mollusca, Gastropoda): sodium pentobarbital is the drug of choice. Mem Inst Oswaldo Cruz 2001; 96(3): 391-392. PMid:11313650. http://dx.doi.org/10.1590/S007402762001000300019 .

Martins-Souza RL, Pereira CAJ, Coelho PMZ, Negrão-Corrêa D. Silica treatment increases the susceptibility of the Cabo Frio strain of Biomphalaria tenagophila to Schistosoma mansoni infection but does not alter the natural resistance of the Taim strain. Parasitol Res 2003; 91(6): 500-507. PMid:14530969. http://dx.doi.org/10.1007/s00436-003-0985-4.

Mendes EA, Lima WS, Melo AL. Development of Fasciola hepatica in Lymnaea columella infected with miracidia derived from cattle and marmoset infections. J Helminthol 2008; 82(1): 81-84. PMid:18053300. http://dx.doi.org/10.1017/S0022149X07873585.

Oliveira S, Fujii T, Spósito E Fa, Martins AMC. Ocorrência de Lymnaea columella Say, 1817 infectada naturalmente por Fasciola hepatica (Linnaeus, 1758), no vale do Ribeira, São Paulo, Brasil. Arq Inst Biol (Sao Paulo) 2002; 69(1): 29-37.

Pereira CAJ, Martins-Souza RL, Corrêa JA Jr, Coelho PMZ, Negrão-Corrêa D. Participation of cell-free haemolymph of Biomphalaria tenagophila in the defence mechanism against Schistosoma mansoni sporocysts. Parasite Immunol 2008; 30(11-12): 610-619. PMid:19067842.

Rondelaud D, Belfaiza M, Vignoles P, Moncef M, Dreyfuss G. Redial generations of Fasciola hepatica: a review. J Helminthol 2009; 83(3): $245-$ 254. PMid:19203397. http://dx.doi.org/10.1017/S0022149X09222528.
Ueta MT. Infecção experimental de Lymnaea columella por Fasciola hepatica. Rev Saude Publica 1980a; 14(1): 43-57. PMid:7433872. http:// dx.doi.org/10.1590/S0034-89101980000100004.

Ueta MT. Ocorrência de infecção natural de Fasciola hepatica Linnaeus, 1758 em Lymnaea columella Say, 1817 no Vale do Paraíba, SP, Brasil. Rev Saude Publica 1980b; 14(2): 230-233. PMid:7221470. http://dx.doi. org/10.1590/S0034-89101980000200010.

Van der Knaap WPW, Meuleman EA, Sminia T. Alterations in the internal defence system of the pond snail Lymnaea stagnalis induced by infection with the schistosome Trichobilharzia ocellata. Parasitol Res 1987 73(1): 57-65. PMid:3809151. http://dx.doi.org/10.1007/BF00536337.

Van der Voort M, Charlier J, Lauwers L, Vercruysse J, Van Huylenbroeck G, Van Meensel J. Conceptual framework for analysing farm-specific economic effects of helminth infections in ruminants and control strategies. Prev Vet Med 2013; 109(3-4): 228-235. PMid:23219140. http://dx.doi. org/10.1016/j.prevetmed.2012.10.017.

Vignoles P, Dreyfuss G, Rondelaud D. Fasciola hepatica: comparative metacercarial productions in experimentally-infected Galba truncatula and Pseudosuccinea columella. Parasite 2015; 22: 15. PMid:25907356. http://dx.doi.org/10.1051/parasite/2015015.

Yoshino TP, Boyle JP, Humphries JE. Receptor-ligand interactions and cellular signalling at the host-parasite interface. Parasitology 2001;123(7 Suppl): S143-157. PMid:11769279. http://dx.doi.org/10.1017/ S0031182001007685. 